Chan's classic study of beat reporters, Negotiating Control.

Again, the chapter on the Fourth Estate does not appear to take account of the large and growing body of academic research on journalists, their perceptions of their roles, values, ethics, and practices, which is now starting to map the commonalities and differences that define journalists across the globe. Of course, one cannot include everything in a book like this, but surely, at least the lists of further reading could be enhanced.

I was also a little puzzled by some of the exercises, which seemed to lack model answers; the ones on subbing news stories, for example.

Another big problem is the lack of interest in Indigenous journalism, let alone the wider Pacific region; a section on indigenisation manages to avoid the word 'aborigine', which also does not appear in the index. The occasional mentions of New Zealand, for example in the chapter on media law, are not enough to make it useful.

It is basic, it is too rough in places, and it is going to infuriate some media academics. But I still found myself flicking through sections with interest, drawn in by the engaging and undoubtedly passionate voice of the writers. If the next edition included expanded, more thoroughly researched references and further reading lists, and material on Indigenous media and the wider region, this could become the classic core text on Oceania media studies.
LYNNE TRENWITH is an Aucklandbased communications academic and consultant.

\section{Can democracy and citizenship be reclaimed?}

Citizenship, by Etienne Balibar. Cambridge: Polity Press. 2015. 180pp. ISBN-13:978-07456-821-9 pbk

I $\mathrm{N}$ LIGHT of recent world events, Pacific Island democracy issues and various articles exploring the concept that democracy is under threat, leading philosopher Étienne Balibar's book Citizenship is a timely publication. The book is a collection of seven lectures, many printed as individual essays, first published as a collection in Italy in 2012.

The book is not an introductory text to the concept and politics of citizenship and democracy, but rather a composite analysis - an argumentation, concluding with seven 'theses' or 'theoretical propositions' in the final chapter. Balibar explores the dialectic around the constitution of citizenship and democracy from ancient Greece onwards and interrogates the different theories and practices of representation, making the distinction between simply an 'authorisation' of representation to that of the power and action of the represented.

He asks why there is a need to argue that democracy and citizenship are 


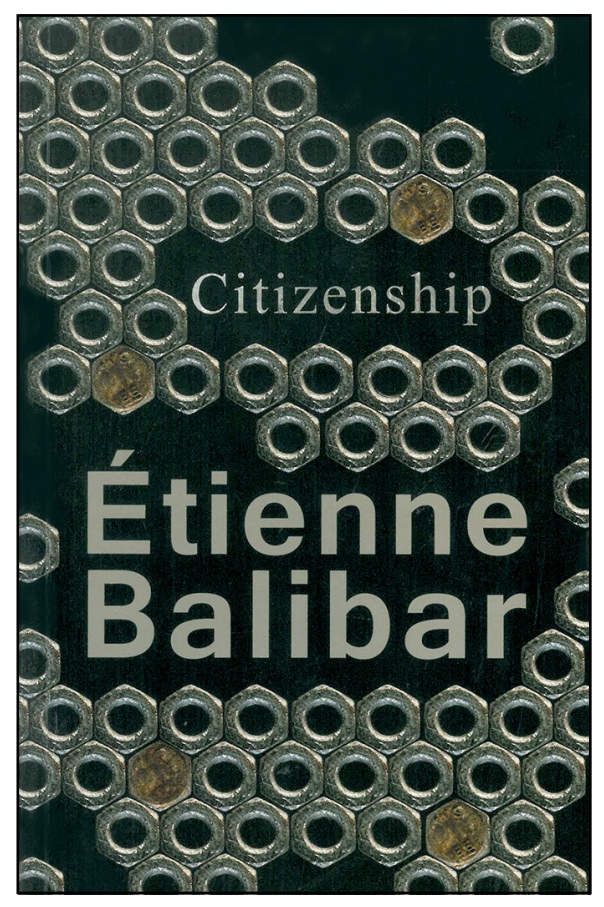

closely related when their relationship seems to lead to insoluble problems. He examines the constant redefining of citizenship and the discriminatory mechanisms that exist to create inclusion and exclusion of political communities. The Western values of individual freedom are explored along with an examination of terminology usage and subsequent framing of the dissident/the rebel/the delinquent.

Balibar explores how a range of tolerable opinions have been and are being excluded from the public sphere and explores the limits of progress that can be made under a 'Welfare State' (or the 'social-national state', as he prefers to term it), by looking at citizenship and the resulting social exclusion and civil conflict.

Recent international events are considered along with the flux of what it is to have national sovereignty and exercise national sovereignty. Post 9/11 events and migration are cited as examples demonstrating an authoritarian turn in functional liberal democracies with a proliferation of laws and procedures defending society against a list of perceived threats.

The pursuit of neo-liberalism with its emphasis on individualism, rational self-interest and privatisation of the public sector functions has triggered a crisis in what it is to be a citizen and what it is to be part of a democracy. Can the 'constitution of citizenship' be fully achieved, he asks? Or is a democracy 'incapable of resisting its own 'de-democratisation' under neo-liberal ideology where governance and mass communication have been substituted for representative democracy.

Balibar concludes by challenging the reader to struggle for the 'democratisation of democracy' and argues that we must return to the idea that a force or political movement can only democratise society if it itself is fundamentally more democratic than the system it opposes in objectives and internal operation. This then becomes a true experience of democratic citizenship. 